\title{
PEACEFUL JIHĀD DAN PENDIDIKAN DERADIKALISASI AGAMA
}

\author{
Sulasman \\ Universitas Islam Negeri (UIN) Sunan Gunung Djati Bandung \\ e-mail: sulasman14@yahoo.com
}

\begin{abstract}
The Islamic Boarding School (Pondok Pesantren) Miftahul Huda was originatelly identical with the radicalism movement not only because of its exclusivism in religious activities, the criticism toward the government, but also the identification of its members with DI/TII movement and FPI. In line with internal and external dynamics, this boarding school reoriented its movement from physical jihād to the path of education and peaceful dakwah or in Lukens-Bull's perspective it is so-called peaceful jihād. The process of self-domestication and the movement of de-radicalization in this boarding was executed by six ways. They are internalizing the values of boarding school, increasing the Islamic perspective, adopting schools system, providing the education of hubb al-watan, using local wisdom, and developing skill education. The strategy of de-radicalization applied by Miftahul Huda Islamic Boarding School is divided into three efforts; preventive de-radicalization, preservative de-radicalization, and curative de-radicalization. The results was shown that the students, alumni, and the boarding schools incorporated in Miftahul Huda Islamic boarding school networking system that appears in peace, moderate, and tolerance appearance.
\end{abstract}

Pondok Pesantren Miftahul Huda semula identik dengan gerakan "radikal" baik karena pandangan eksklusivismenya dalam beragama, kritisisme terhadap Pemerintah, maupun karena keidentikkan beberapa personalnya dengan gerakan DI/TII dan FPI. Sejalan dengan dinamika internal dan eksternal, pondok pesantren ini pun mereorientasi gerakannya dari jihād fisik ke jalur pendidikan dan dakwah damai atau dalam perspektif Lukens-Bull dikenal sebagai jihad damai (peaceful jihād). Proses menjinakkan diri dan gerakannya, yang dikenal dengan deradikalisasi, dilalui oleh pondok pesantren ini dengan enam cara, yakni internalisasi nilai-nilai pesantren, perluasan perspektif keislaman, adopsi sistem sekolah, pendidikan hubb al-wațan, penggunaan local wisdom, dan pendidikan keterampilan. Upaya deradikalisasi yang dilakukan Pondok Pesantren Miftahul Huda berkisar pada tiga strategi, yakni pencegahan, pemeliharaan budaya damai, dan pemulihan bagi yang terdampak radikal. Hasilnya, para santri, alumni, dan pesantren yang tergabung dalam sistem jaringan Pondok Pesantren Miftahul Huda muncul dalam wajah damai, moderat, dan toleran.

Keywords: Islam, jihād, pendidikan, deradikalisasi, pesantren 


\section{A. Pendahuluan}

Satu dasawarsa terakhir, perhatian dunia internasional terhadap isu radikalisme di Dunia Muslim sangat kuat, terutama pasca kemenangan Taliban di Afganistan, tragedi 11 September 2001 di USA, serta ISIS di Syiria dan Irak. Kasus terakhir adalah terkait dengan penyerangan Charlie Hebdo pada tanggal 7 Januari 2015, di Perancis yang sangat menyita perhatian dunia Barat. Padahal untuk kasus penembakan tiga orang Muslim di Chapel Hill North Carolina, USA pada tanggal 11 Pebruari 2015, dunia Barat bungkam seribu bahasa. Seringkali serangkaian pemboman dan teror yang terjadi di belahan dunia, diklaim Barat dilakukan oleh kalangan Muslim. Persepsi ini jelas menjadi beban psikologis tersendiri bagi umat Islam di seluruh dunia, sekalipun Barat menyadari bahwa radikalisme bukanlah karakter seluruh Muslim.

Salah satu lembaga yang mendapat sorotan kalangan Barat adalah pondok pesantren. Lembaga ini diklaim sebagai tempat penyemaian paham Islam radikal sekaligus breeding grounds for terrorist (tempat persemaian teroris). ${ }^{1}$ Hefner mengatakan, "Since 9/11 attacks in the United States and Ocktober 2002 Bali bombings in Indonesia, Islamic Schools in Southeast Asia have been the focus of international attention". ' Hal serupa juga disampaikan oleh Martin van Bruinessen, terutama dalam konteks keberadaan pondok pesantren tradisional berbasis "Jama'ah Islamiah" di Indonesia.3 Journal of Asian Affair menuduh pondok pesantren dan madrasah tradisional di Indonesia serupa dengan madrasah di Pakistan. Dikatakan, "like Pakistan's madrasa, there exist an entire education system, "the pesantren", which is independent of the government and provide with Islamicfertile ground to train the children of the poor in the mould of radical Islam".4

\footnotetext{
${ }^{1}$ Beberapa pencitraan itu, misalnya dapat ditemukan dalam Timothy Mapes, "Indonesia School Has Chilling Roster of Terrorist Alumni," dalam Wall Street Journal, 3 September 2003; Jane Parlez, "Saudis Quietly Promote Strict Islam in Indonesia,"New York Times, 5 Juli 2003; Andrew Marshal, "The Threat of Ja'far", New York Times, 10 Maret 2002.

${ }^{2}$ Robert W. Hefner, Making Modern Muslims, The Politics of Islamic Education in Southeast Asia, (Univerity of Hawaii Press, 2009), h. 1.

3Martin van Bruinessen, "Tradisionalist and Islamist Pesantrens in Contemporary Indonesia", dalam Farish A. Noor, etal (ed.), The Madrasa in Asia, Political Activism and Transnational Linkages, (Amsterdam University Press, 2008), h. 217. Dalam hal ini, ia berfokus pada keberadaan Pesantren AlMukmin, Ngruki, dan jaringan-jaringannya.

${ }^{4}$ S.S. Misra, "Islamic Terrorism in Indonesia", dalam ASIAN Affairs, September 2003. Secara khusus, hal ini dialamatkan ke Pesantren Al-Mukmin, Ngruki, yang dilabeli sebagai pusat jaringan Muslim
} 
Istilah "radikalisme" sebenarnya bukan konsep asing dalam ilmu sosial. Disiplin politik, sosiologi, dan sejarah sejak lama telah menggunakan terma ini untuk menjelaskan fenomena sosial tertentu. Sejarawan Kartono Kartodirjo, misalnya, menggunakan "radikal" sebagai indikator sikap penolakan total terhadap kondisi yang sedang berlangsung. Secara khusus, term ini digunakan untuk menggambarkan gerakan protes petani yang menggunakan simbol agama dalam menolak seluruh aturan dan tatanan yang ada. ${ }^{5}$ Sementara Adeed Dawisha menggambarkan radikalisme sebagai sikap jiwa yang membawa kepada tindakan-tindakan yang bertujuan melemahkan dan mengubah tatanan politik mapan dan biasanya dengan cara-cara kekerasan dan menggantinya dengan sistem baru. ${ }^{6}$

Mengadopsi temuan Horace M. Kallen, radikalisme sosial sedikitnya memiliki tiga ciri mainstream dalam melakukan gerakannya. Pertama, radikalisme merupakan respons terhadap kondisi yang sedang berlangsung, baik dalam bentuk evaluasi, penolakan, atau bahkan perlawanan. Masalah-masalah yang ditolak berupa asumsi, ide, lembaga atau nilai-nilai yang dipandang bertanggungjawab terhadap kelangsungan kondisi yang ditolak. Kedua, radikalisme tidak berhenti pada upaya penolakan, melainkan terus berupaya mengganti tatanan tersebut dengan bentuk tatanan lain. Upaya ini mengandung program atau pandangan dunia tersendiri untuk mengubah keadaan secara mendasar. Ketiga, kuatnya keyakinan kaum radikalis akan kebenaran program atau ideologi yang mereka bawa, sembari dibarengi dengan penolakan kebenaran sistem lain yang akan diganti. ${ }^{7}$

militan di Indonesia yang secara internasional merupakan Jaringan al-Qaeda. International Crisis Group, "Al-Qaeda in Southeast Asia: The Case of the "Ngruki" Network in Indonesia," ICG Asia Breafing, No. 20, Jakarta/Brussels, 8 Januari 2002.

${ }^{5}$ Bahtiar Effendi dan Hendro Prasetyo, pengantar dalam Bahtiar Effendi dan Hendro Prasetyo (peny.), Radikalisme Agama, (Jakarta: PPIM-IAIN, 1998), h. xvi.

"Menurur Adeed Davisha, ada perbedaan esensial antara "terorisme" dengan "radikalisme". Kalau "terorisme" hanya merupakan salah satu di antara berbagai instrumen kebijakan para pelakunya, sedang "radikalisme" adalah esensi dari kebijaksanaan itu sendiri; radikalisme juga mencakup nilainilai, tujuan dan concern dari orang-orang yang merumuskan kebijaksanaan tersebut. Lihat Azyumardi Azra, Pergolakan Politik Islam: Dari Fundamentalisme, Modernisme hingga Postmodernisme, (Jakarta: Paramadina, 1996), h. 147.

${ }^{7}$ Azyumardi Azra, Pergolakan Politik Islam..., h. xviii. Dalam konteks ini, menurut Hassan Hanafi, kekerasan terjadi di lingkungan tertentu ketika ia menjadi satu-satunya jalan dan media untuk mengekspresikan eksistensi kemanusiaan. Kekerasan dimulai dari situasi yang terbentuk oleh tiga elemen. Pertama, perasaan mendalam dari individu, kelompok dan bangsa akan ketidakadilan dan keputusasaan; kedua, ketidakberdayaan individu, kelompok dan masyarakat dalam mengubah ketidak- 
Dalam konteks keagamaan, nampaknya belum ada kesepakatan terminologis untuk menggambarkan gerakan radikal. ${ }^{8}$ Oliver Roy menyebut gerakan Islam yang berorientasi pada pemberlakuan syariat Islam sebagai Islam Fundamentalis, yang ditunjukkan dengan gerakan Ikhwanul Muslimin, Hizbut Tahrir, Jami'ati Islami dan Front of Islamic Salvation (FIS). ${ }^{9}$ John L. Esposito lebih memilih menggunakan istilah revivalisme Islam atau aktivisme Islam, yang memiliki akar tradisi Islam. ${ }^{10}$ Muhammad Abid al-Jabiri menggunakan istilah ekstremisme Islam. Kelompok Islam ekstrem biasanya mengarahkan permusuhan dan perlawanannya kepada gerakan-gerakan Islam mainstream (tengah) atau "moderat". 11

Kerangka yang dikonstruk Martin E. Marty nampaknya cukup relevan diterapkan untuk melihat gejala "kekerasan atas nama agama". Menurutnya, ciri yang utama adalah oppositionalism (paham perlawanan), yakni paham perlawanan terhadap ancaman yang dipandang membahayakan eksistensi agamanya, apakah dalam bentuk modernitas atau modernisme, sekularisasi, dan tata nilai Barat pada umumnya. ${ }^{12}$ Sikap melawan atau berjuang (fight) dilakukan, di antaranya dengan melawan kembali (fight back) kelompok yang mengancam keberadaan atau identitas yang menjadi tatanan hidup; berjuang untuk (fight for) menegakkan cita-cita yang meliputi persoalan hidup secara umum, seperti keluarga atau institusi sosial; berjuang dengan (fight with) kerangka nilai atau identitas tertentu yang berasal dari warisan masa lalu maupun kontruksi yang baru; berjuang melawan (fight against) musuh-musuh tertentu yang muncul

adilan tersebut melalui segala cara tanpa kekerasan; ketiga, tidak adanya dialog antara pelaku ketidakadilan dan korbannya, atau mungkin ada namun sekedar dialog semu (bisu). Lihat: Hassan Hanafi, Agama, Kekerasan dan Islam Kontemporer, terj. Ahmad Najib, (Yogyakarta: Jendela, 2001), h. 54.

8Banyak ilmuwan yang menyamakan istilah radikalisme agama dengan fundamentalisme (ușūliyyūn), "kaum Islamis" (islāmiyyun), "kaum otentik atau asli" (așliyyun), "pengikut para sahabat utama (salafiyyūn), "militant" atau bahkan "neo-fundamentalisme", karena memiliki kemiripan-kemiripan tertentu yang menyerupai ciri-ciri dalam radikalisme. Azyumardi Azra, Pergolakan Politik Islam: Dari Fundamentalisme, Modernisme hingga Postmodernisme, (Jakarta: Paramadina, 1996), h. 109.

${ }^{9}$ Oliver Roy, The Failure of Political Islam, (London: I.B. Tauris \& Co. Ltd., 1994), h. 2-4.

${ }^{10}$ John L. Esposito, The Islamic Threat Myth or Reality?(Oxford: Oxford University Press, 1992), h. 7-8.

${ }^{11} \mathrm{Al}$-Jabiri menunjukkan perbedaan dari gerakan Islam ekstrem di masa kontemporer ini. Gerakan-gerakan ekstemis masa lalu mempraktikkan ekstremisme pada tatanan akidah, sedangkan gerakan-gerakan ekstrem kontemporer menjalankannya pada tataran syariah dengan melawan mazhab-mazhab moderat. Muhammad Abid al-Jabiri, Agama, Negara dan Penerapan Syariah, terj. (Yogyakarta: Fajar Pustaka, 2001), h. 139-149.

${ }^{12}$ Azyumardi Azra, Pergolakan Politik Islam ..., h. 109. 
dalam bentuk komunitas atau tata sosial keagamaan yang dipandang menyimpang; dan terakhir, mereka melakukannya dalam kerangka perjuangan atas nama (fight under) Tuhan. ${ }^{13}$

Pada masa Orde Baru, kalangan Islam fundamentalis dan radikal dapat dibungkam dan dikontrol oleh pemerintah, sekalipun seperti api dalam sekam. Namun ketika Reformasi digulirkan, kalangan fundamentalis dan radikal Islam kemudian bersemi kembali dan menjamur. Gerakannya dapat terasa, sekalipun sulit diidentifikasi kalangan awam. ${ }^{14}$ Atas nama HAM serta kebebasan akademis dan berpendapat, ragam paham (isme), termasuk fundamental, radikal, dan liberal dilindungi eksistensinya selama tidak berujung pada tindakan "makar" dan mengancam keutuhan NKRI. Hanya saja, tidak jarang gerakan radikalisme Islam ini berujung pada ideologi terorisme, khususnya teror bom yang terus menghantui harmoni dan keutuhan bangsa ini.

Dalam konstalasi ideologi serta kegaduhan kontestasi politik kekuasaan di Indonesia, Islam radikal terus meluaskan rambahan domain (network) dan operasi "jihad"nya, termasuk menggarapkalangan pondok pesantren salafiyah. Lembaga pendidikan Islam ini diposisikan sebagai objek operasi kalangan radikal, melalui brain washing tentang "negara ideal", euphoni tertang kezaliman dan marginalisasi kekuasaan (negara) terhadap mereka, serta persekongkolan negara dengan para "musuh Allah" (negara-negara Barat Kristen dan Yahudi). Sikap inilah yang memunculkan sikap antipati para korban terhadap kekuasaan, yang jika dipicu sedikit saja dapat memunculkan sikap radikal mereka. ${ }^{15}$

${ }^{13}$ Bahtiar Effendi dan Hendro Prasetyo, pengantar dalam Bahtiar Effendi dan Hendro Prasetyo (ed.), Radikalisme Agama, h. xix.

${ }^{14}$ Sudirman Tebba menggambarkan radikalisme agama dan runtuhnya nilai-nilai pluralisme di era reformasi sebagai permasalahan keberagamaan yang sangat kompleks pasca orde baru. Kerusuhan yang berbau SARA (suku, agama, ras dan antargolongan) pasca orde baru banyak dilandasi oleh beberapa faktor yang berbeda dengan menarik agama ke dalam konflik tersebut. Sebut saja karena kepentingan ekonomi dan politik baik pada tingkat elit maupun massa. Misalkan etnis Madura di Kalimantan yang telah hidup turun temurun di daerah-daerah tersebut. Mereka menguasai sektor perdagangan. Keadaan itu mengurangi peluang usaha penduduk asli di daerah tersebut. Karenanya usaha yang dikembangkan masyarakat penduduk asli adalah dengan cara mengusir mereka dari daerah itu. Inilah kemudian yang memicu konflik sosial. Sudirman Tebba, Islam Pasca Orde Baru, (Yogyakarta: Tiara Wacana, 2001), h. 138.

15Komaruddin Hidayat lebih melihat gejala radikalisme agama lebih bersifat psikologis-sosiologis akibat politik dan agama tidak berjalan secara semestinya. Perasaan merasa "tersisih", "tertindas", tidak diperhitungkan secara politis bahkan dianggap sebagai "beban" atau "pengacau" pembangunan me- 
Namun, tidak semua kalangan pesantren salafiyah bersikap simpatik terhadap keberadaan Islam radikal ini. Umumnya mereka tidak mau tahu tentang eksistensi dan gerakan mereka. Sebagian mereka waspada terhadap gerakan Islam radikal ini, sembari membentengi diri dari upaya-upaya yang akan menyeret pesantren salafiyah ke pusaran Islam radikal tersebut. Salah satu pondok pesantren yang berhasil "menjinakkan diri" dan membentengi diri dari paham radikal adalah Pondok Pesantren Salafiyah Miftahul Huda Manonjaya, Tasikmalaya, Jawa Barat.

Dengan cabangnya yang hampir 800 buah dan memiliki total warga pesantrennya lebih dari 30.000 orang (kiai dan santri), Pesantren Miftahul Huda ini memiliki potensi untuk menjadi agent of change untuk menyemaikan Islam Damai (peaceful Islam atau smile Islam). Dalam konteks lokal Jawa Barat, peran dan kontribusi positif Pondok Pesantren Miftahul Huda ini telah terasa dalam upaya memajukan pendidikan Islam, khususnya pemihakannya terhadap kalangan miskin, termasuk dalam upaya meredam konflik sosial-keagamaan. Apabila Jawa Barat kemudian muncul sebagai wilayah yang paling banyak kasus kekerasan atas nama agamanya, hal ini dapat dipastikan bahwa peran pondok pesantren salafiyah, termasuk Pondok Pesantren Miftahul Huda, sangatlah minor. Dalam kiprahnya, kontribusi Pondok Pesantren Miftahul Huda terhadap pemberdayaan dan pengembangan masyarakat telah dirasakan secara nyata oleh masyarakat, baik dalam bidang dakwah dan pendidikan maupun dalam bidang sosial, budaya, dan politik. ${ }^{16}$ Namun, im potensia, kekuatan yang dimiliki Pondok Pesantren Miftahul Huda tersebut dapat menjadi "potensi" yang dapat mengancam keharmonisan bangsa jika kemudian negara dan masyarakat "abai" dan tidak menjadikannya sebagai bagian dari partner dan pilar negara.

Kajian tentang Pondok Pesantren Miftahul Huda ini bukanlah kajian pertama, karena terdapat sejumlah kajian sebelumnya yang mengonsentrasikan

rupakan sumber konflik utama yang berujung pada sikap radikalisme agama. Komaruddin Hidayat, Tragedi Raja Midas: Moralitas Agama dan Krisis Modernisme, (Jakarta: Paramadina, 1998), h. 184.

16Mohamad Mustari, Peranan Pesantren dalam Pembangunan Pendidikan Masyarakat Desa, (Jakarta: Haja Press, 2011), cet. II; Mahrus As'ad, "Sumbangan Pesantren terhadap Pencapaian Tujuan Pendidikan Nasional”, Disertasi, tidak diterbitkan, (Bandung: Pascasarjana UIN SGD, 2010); Insan M. Agusandi, "Perkembangan Pondok Pesantren Miftahul Huda dan Dampaknya terhadap Kehidupan Sosial Keagamaan Kabupaten Tasikmalaya (1980-2009)”, Skripsi, (Bandung: Jurusan Pendidikan Sejarah UPI, 2013). 
diri pada kajian-kajian tertentu dari Pondok Pesantren Miftahul Huda. Di antaranya: (a) Syahidin, "Komunikasi Kiai-Santri di Pondok Pesantren Miftahul Huda Manonjaya Tasikmalaya dalam Membina Kepribadian: Suatu Upaya Pengembangan Komunikasi Guru-Murid dalam Pendidikan Umum", tesis, IKIP Bandung, tidak dipublikasikan 1994; (b) Yuyun Sunarya, "Hubungan Fungsional Radio FM Rasimuda terhadap Pondok Pesantren Miftahul Huda ManonjayaTasikmalaya", skripsi Jurusan KPI Fakultas Dakwah UIN Sunan Kalijaga Yogyakarta, 2008; (c) Insan M. Agusandi, "Perkembangan Pondok Pesantren Miftahul Huda dan Dampaknya terhadap Kehidupan Sosial Keagamaan Kabupaten Tasikmalaya (1980-2009)", skripsi di Jurusan Pendidikan Sejarah UPI Bandung, 2013. Ketiga karya tulis tersebut secara khusus dan eksplisit mengambil Pondok Pesantren Miftahul Huda sebagai objek kajian.

Sementara itu, terdapat pula beberapa kajian yang mengambil Pondok Pesantren Miftahul Huda sebagai salah satu kajian di dalamnya dan mengkomparasikannya dengan institusi lainnya. Di antaranya adalah: (a) Mohamad Mustari, Peranan Pesantren dalam Pembangunan Pendidikan Masyarakat Desa. Jakarta: Haja Press, cet. II, 2011; dan (b) Mahrus As'ad, “Sumbangan Pesantren Pada terhadap Pencapaian Tujuan Pendidikan Nasional”, disertasi Pascasarjana UIN SGD, tidak diterbitkan, 2010.

Penelitian ini menggunakan metode kualitatif dengan pendekatan studi kasus. Penelitian mencoba mendeskripsikan upaya Pondok Pesantren Miftahul Huda Manonjaya Tasikmalaya Jawa Barat dalam mengkonstruk Islam Damai, serta upayanya menjalani proses pendidikan yang membentuk Muslim dan Islam yang damai atau -meminjam istilah Lukens Bull- menjalani proses jihad damai (peaceful jihād). Pengumpulan data dilakukan melalui observasi, wawancara, dan studi dokumentasi.

\section{B. Sekilas tentang Pesantren Miftahul Huda}

Pondok pesantren ini didirikan oleh KH. Choer Affandi, terkenal dengan sebutan Uwa Ajengan, pada tahun 1967, yang sekaligus menjadi kiai pimpinan pesantren. ${ }^{17}$ Sepeninggal dia pada tahun 1994, Pondok Pesantren Miftahul

\footnotetext{
${ }^{17}$ Pondok Pesantren Miftahul Huda, Sejarah Berdirinya Pesantren Miftahul Huda Manonjaya, Tasikmalaya, 1969, h. 3.
} 
Huda dipimpin oleh putranya yaitu KH. Asep Ahmad Maoshul, dibantu oleh Dewan Kiai, yang terdiri dari para putra, menantu, dan cucu Uwa Ajengan. ${ }^{18}$ Pondok Pesantren Miftahul Huda mengkhususkan diri dalam pengajian kitabkitab klasik dengan metode tradisional, yakni bandungan, sorogan, dan munāzarah. ${ }^{19}$ Sekalipun ada penjenjangan dan pengkelasan, di pondok pesantren ini tetap mempertahankan sistem tradisional (salafiyah)-nya dan tidak menggunakan sistem klasikal formal dalam sistem pendidikannya. 20

Pondok Pesantren Miftahul Huda merupakan lembaga pendidikan Islam yang dengan segala kelebihan dan kekurangannya selalu mengupayakan agar para santrinya mampu ber-akhlāq al-karīmah dan mendapat ilmu yang bermanfaat. Untuk mencapai hal tersebut, Pondok Pesantren Miftahul Huda menuangkannya dalam tiga program pondok pesantren, yaitu mencetak: (a) 'ulamā' al-'āmilīn (ulama yang mampu mengamalkan ilmunya); (b) imām almuttaqīn (memimpin umat untuk bertakwa); (c) muttaqīn (manusia yang bertahan dalam ketakwaan). Usaha ke arah tersebut ditunjang dengan strategi luar (zāhiriyyah) berbentuk kegiatan-kegiatan pendidikan dan pembinaan selama 24 jam dan strategi dalam (baținiyyah) berbentuk ibadah-ibadah ritual yang diberjama'ahkan, seperti; riyāẹah, ${ }^{21}$ tadarrus al-Qur'ān, shalat berjama'ah awal waktu, shalat Tahajjud dan shalat Duhā. Semuanya ada dalam kerangka peraturan sebuah lembaga yang ditopang dengan administrasi, komputer sistem online, dan fasilitas-fasilitas pelayanan lainnya.

Pesantren, yang kini terletak di areal tanah seluas 8 hektar, dihuni lebih dari 3.000 santri. Alumni nya telah cukup banyak dan tersebar di seluruh pelosok Indonesia. ${ }^{22}$ Para alumni Pondok Pesantren Miftahul Huda banyak

\footnotetext{
18Wawancara dengan KH Abdul Aziz, salah satu Dewan Kiai Pondok Pesantren Miftahul Huda, 23 Januari 2015.

${ }^{19}$ Bandungan (atau bandongan, Jawa) adalah sistem pembelajaran kitab kuning dengan cara santri menyimak bersama-sama pembacaan dan penjelasan kitab kuning yang dilakukan oleh kiai. Sorogan adalah sistem pembelajaran kitab kuning dengan cara santri belajar kitab tertentu pada kiai secara sendiri-sendiri. Sedangkan, munāzarah atau dikenal pula dengan istilah mudhakarah atau muțala'ah adalah pembelajaran kitab kuning melalui kegiatan telaah bersama atau metode diskusi di antara santri-santri, yang umumnya dilakukan oleh santri-santri senior.

20Mahrus As'ad, "Sumbangan Pesantren...," h. 76.

${ }^{21}$ Riyāọah di sini dimaknai oleh Ustad Anas Shalahuddin, salah satu alumi Ponpes Miftahul Huda, sebagai pembiasaan diri untuk mendekatkan diri kepada Allah (muqarrabah dan muraqqabah) melalui serangkaian amalan-amalan sunnah dan dzikir. Anas Shalahuddin, Wawancara, 13 Februari, 2015.

${ }^{22}$ Mahrus As'ad, “Sumbangan Pesantren...," h. 76.
} 
yang telah berkiprah di masyarakat, baik di dalam negeri, khususnya Jawa Barat, maupun di luar negeri dalam berbagai sektor professional. Banyak di antara alumninya membuka (atau dibukakan) pesantren, yang kemudian mengakuinya sebagai cabang, atau menginisiasi kelembagaan mereka sebagai bagian dari Pondok Pesantren Miftahul Huda. Keterikatan pusat dan cabang inilah yang merupakan salah satu ciri dari tradisi pesantren dari pondok pesantren ini. Karenanya, melaui pola ini, menurut KH. Abdul Fatah, Pondok Pesantren Miftahul Huda memiliki 1.000 lebih cabang pesantren yang tersebar di daerah Jawa dan Sumatera. ${ }^{23}$ Angka yang sama ini didapat pula dari website resmi Pondok Pesantren Miftahul Huda.

Menurut KH. Saeful Uyun, ${ }^{24}$ salah satu ciri pesantren yang berinduk ke Pondok Pesantren Miftahul Huda adalah penggunaan nama "Miftahul Huda" sebagai nama pesantrennya ditambah dengan nama daerah atau nomor, misalnya Miftahul Huda II. Selainnya, nama pesantrennya diawali dengan kata "Miftah" seperti Miftahul Jannah, Miftahul Huda, dan Miftahul Ulum atau diakhiri dengan kata "Huda", seperti Manbaul Huda dan Thariqul Huda.

\section{Keidentikkan Pondok Pesantren Miftahul Huda Masa Awal dengan Paham "Radikal”}

Sebagaimana disebutkan di atas bahwa "radikal" dimaknai sebagai pemikiran dan sikap oposisional terhadap kondisi dan sistem yang sedang berjalan, serta berupaya untuk mengubahnya sekemampuan mungkin. Sikap ini seringkali diserupakan dengan sikap eksklusivisme dan puritan. Pada tahap pemikiran, radikal ekuivalen dengan kritisisme, sedangkan dalam kerangka politik istilah ini diekuivalenkan dengan oposisi. Radikal tidak harus diidentikkan dengan kekerasan, anarkis, destroyer, atau bahkan teroris. Dalam konteks Pondok Pesantren Miftahul Huda, unsur-unsur tersebut tidak Nampak. Oleh karena itu di pondok pesantren ini, radikal dimaknai sebagai upaya kritis, oposisi diam terhadap kondisi mainstream, dan berupaya aktif untuk mengubahnya sesuai dengan "konstruks" yang dimilikinya.

23Wawancara dengan KH Abdul Fatah, salah satu pengasuh Pondok Pesantren Miftahul Huda Pusat, 23 Januari 2015.

${ }^{24}$ Salah satu Ketua Hamida (Himpunan Alumni Miftahul Huda) dan Pimpinan Pondok Pesantren Gempalan, Kecamatan Panjalu, Ciamis. Wawancara 22 Januari 2015. 
Berdasarkan pada kriteria Islam Radikal dari Marty di atas, Pondok Pesantren Miftahul Huda memiliki kerekatan historis dengan paham dan gerakan "radikal". Kerekatan ini dipicu oleh beberapa hal. Pertama, kerekatan historis sosok pendiri pondok pesantren ini, yaitu KH. Choer Affandy dengan gerakan DI/TII karena ia pernah menjadi salah satu elitnya. Kedua, sikap kritisisme elit, santri, dan simpatisan Pondok Pesantren Miftahul Huda terhadap Pemerintah Orde Baru. Ketiga, beberapa teman seperjuangan KH. Choer Affandy dan santrisantri generasi awalnya masih memiliki ideologi NII. Keempat, sebagian kalangan Pondok Pesantren Miftahul Huda memandang keberislaman diri dan kelompok mereka adalah keberislaman yang paling benar, sementara yang lain dianggap memiliki kekurangan atau bahkan "salah." Kelima, pandangan eksklusif kalangan pesantren terhadap "dunia luar", seperti pemerintah dan masyarakat pro-Pemerintah beserta produk-produk turunannya, seperti program sekolah, Keluarga Berencana (KB), uji screening, dan asas tunggal.

Pengalaman KH. Choer Affandi ${ }^{25}$ dengan "Islam Politik" mulai ketika ia sedang nyantri di Pesantren Singaparna Tasikmalaya pimpinan KH. Zaenal Musthofa, dan Pesantren Gunung Puyuh Pimpinan KH. Ahmad Sanusi. Di kedua pesantren ini, dia dididik Rūh al-Jihād oleh gurunya sejak mulai mengaji kitab Ajurūmiyah hingga fundamental tauhid. Gelora jihad pun muncul di saat ia mendengar perlakukan tidak manusiawi tentara Jepang terhadap KH. Zaenal Mustofa, ketika terjadi pemberontakan Pesantren Sukamanah pimpinan gurunya terhadap Jepang. Meskipun dia tidak secara langsung ikut serta dalam pemberontakan tersebut, Jepang pun mencurigainya dan berusaha menangkapnya. Hanya saja, ia mampu menghindari sergapan-sergapan militer Jepang. Namun, ajaran guru-gurunya dan gerakan anti-kolonialnya telah sangat kuat berpengaruh pada diri KH. Choer Affandy, sehingga menumbuhkembangkan jiwa "pemberontakan" dan obsesi ideologi Negara Islam.

Jiwa anti-kolonial ini pulalah yang mendorong KH. Choer Affandy untuk bergabung dengan Hizbullah, sayap paramiliter yang banyak diisi oleh

${ }^{25} \mathrm{KH}$. Choer Affandi bernama kecil Onong Husen, lahir pada hari Senin tanggal 12 September 1923 M di kampung Palumbungan Desa Cigugur Kecamatan Cigugur Kewedanan Cijulang Ciamis, dari Pasangan Raden Mas Abdullah bin Hasan Ruba'iyang masih mempunyai keturunan Raja Mataram dan Siti Aminah binti Marhalan yang mempunyai keturunan dari Wali Godog Garut. Menurut KH. Abdul Fatah, dalam darah Onong Husen mengalir darah bangsawanan dan darah ulama yang dominan dalam membentuk kepribadian KH. Choer Affandi. Hal ini terbukti dengan sikap Uwa yang sangat bergairah dalam mencari ilmu, baik ilmu-ilmu agama maupun ilmu pengetahuan umum. 
kalangan santri dan kiai, untuk melawan Belanda di kala NICA dan Belanda berkehendak menjajah kembali Indonesia. Pasca Perjanjian Renville (17 Januari 1948), sebagian besar wilayah Indonesia, termasuk Jawa, diklaim sebagai bagian dari Belanda. Pusat pemerintahan Indonesia pun pindah ke Yogyakarta. Semua pasukan militer RI dan faksi-faksi para-militer diperintahkan untuk melakukan longmarch ke Yogyakarta. Pada saat itulah, gerakan gerilya DI/TII menguat di beberapa daerah, terutama di Jawa Barat, yang salah satunya bersikukuh untuk mempertahankan wilayah-wilayah Indonesia dari tentara Inggris dan Belanda. Mereka pun bergerilya pada wilayah-wilayah yang ditinggalkan pasukan militer RI.

Pasca Konferensi Meja Bundar tanggal 27 Desember 1949, sebagian besar Jawa kemudian diakui lagi sebagai bagian dari Indonesia dan Pemerintah Pusat di Jakarta meminta DI/TII untuk melebur ke dalam Tentara Rakyat Indonesia (TRI). Sebagian anggota DI/TII menolak untuk mengembalikan wilayahwilayah yang dikuasainya ke dalam pangkuan Pemerintah Pusat. Maka terjadilah peperangan antara DI/TII dan Tentara Nasional Indonesia (TNI) yang berlangsung dari tahun 1949-1962. Pada waktu itu, KH. Choer Affandy merupakan salah satu petinggi DI/TII yang cukup dekat dengan Kartosuwiryo, karena merupakan salah satu alumni "Institute Suffah".26 Di kala pasukan DI/TII "kalah perang", KH. Choer Affandy "Turun Gunung" pada 1962 ketika terjadi peristiwa operasi "Pasukan Gabungan Rakyat Berantas Tentara Islam" (Pagar Betis) di bawah komando A.H. Nasution. Ia menyerahkan diri kepada Pemerintah RI serta dapat diterima dan mendapatkan perlakukan yang baik dari Pemerintah RI. ${ }^{27}$

Ia mempunyai anggota (anak buah) dan simpatisan yang tidak sedikit, baik ketika masih aktif di DI/TII maupun ketika sudah "kembali ke pangkuan Ibu Pertiwi". Terlebih kemudian ketika ia melakukan reorientasi "perjuangan", dari ideologi DI/NII yang menekankan perjuangan fisik menjadi gerakan pendidikan, dakwah, dan sosial budaya. Sejak saat inilah, proses "penjinakkan diri" atau deradikalisasi dimulai di pesantren ini. KH. Choer Affandy, menurut penuturan Sardjono Kartosuwirjo, putra ke-12 Kartosuwirjo, tidak lagi mau

\footnotetext{
26Wawancara dengan KH. Soleh Nashihin, salah satu pimpinan Pondok Pesantren Miftahul Huda Pusat, Tasikmalaya, 5 Februari 2015.

${ }^{27} \mathrm{KH}$. Abdul Fattah, Awal Mula Uwa Ajengan Datang ke Manonjaya, (Bandung: Wahana Iptek Bandung, 2010), h. 1.
} 
bergabung dengan DI/NII bahkan untuk sekalipun berbicara DI/NII enggan menanggapinya. Hal serupa diungkapkan KH. Abdul Fatah, menantu KH. Choer Affandy, bahwa beberapa kali Danu Muhammad Hasan (salah satu elit DI/TII dan ayah dari Hilmi Aminudin (Ketua Majelis Syuro PKS), menghubungi K. H. Choer Affandydan keluarga untuk membicarakan perkembangan DI/NII, tapi dia enggan menanggapinya.

Pada era tahun 1970-1980an, sikap kritis terhadap pemerintah dan masyarakat terus ditampakkan KH. Choer Affandy dan kalangan pesantren. Sehingga ia dan pesantren dikesani sebagai salah satu kiai dan lembaga yang "keras" dan "anti pemerintah" atau dengan kata lain "radikal". Sikap ini ditunjukkan dengan sikap keengganan untuk menerima Pancasila sebagai asas tunggal dan UndangUndang Dasar 1945, karena dianggap mengambil hukum, selain hukum Allah (al-Qur'an dan Hadits). Sebagian dari mereka menolak untuk ikut Pemilu dan program-program dari pemerintah seperti sekolah, KB, dan transmigrasi. Mereka pun menolak bantuan dari pemerintah dalam bentuk apa pun. Mereka berprinsip harus mandiri (independen) dalam segala hal, serta menghindari campur tangan pemerintah dalam sistem pendidikan pesantrennya, termasuk tidak menerima bantuan-bantuan untuk pengembangan pesantren, seperti pengadaan Ruang Kobong Baru (RKB), beasiswa, dan "intervensi" kurikulum pesantren. Dalam setiap ceramah dan pengajian, sikap ini ditunjukkan dengan sikap kritis, curiga, dan antipati terhadap program pemerintah dan masyarakat pendukungnya.

Pada diri santri-santri generasi awal, yang kemudian mereka menjadi kiaikiai pesantren yang berafiliasi ke Pondok Pesantren Miftahul Huda pusat pun masih nampak. Pada sebagian pesantren cabang Miftahul Huda masih ditemukan kelompok yang belum menerima Pancasila sebagai asas tunggal, menolak upacara bendera, tidak mau mengibarkan Bendera Merah Putih, menolak beberapa Lagu Nasional (Kebangsaan), dan menolak sistem sekolah. Sebagian mereka juga menilai diri mereka sebagai "komunitas eksklusif" dan menilai praktek keberislaman golongan yang lain sebagai yang lebih rendah.

Sikap-sikap inilah yang kemudian dianggap sebagai peluang dari kalangan radikal Islam, seperti DI KW IX, Jama'ah Islamiyyah (JI), Majelis Mujahidin Indonesia, FPI, dan HTI. Sehingga menurut beberapa informan bahwa kelompok-kelompok tersebut masih terus berusaha untuk mengajak dan menyeret mereka untuk gabung pada kelompok-kelompok pengusung paham 
transnasional, khilafatisme, dan Islamisme. Misalnya, pada tahun 1980-an, pasca Revolusi Iran, ada upaya dari Ajengan Marzuki untuk menghidupkan kembali DI/NII. Demikian pula, Abdullah Sungkar dan Abu Bakar Ba'asyir pernah mengajak kalangan pesantren untuk membentuk Jama'ah Islamiyah.

\section{Perubahan Orientasi Menuju Peaceful Jihād}

Hal-hal di atas merupakan gambaran pemikiran dan pola perilaku sebelum tahun 1990-an. Menurut KH. Soleh sikap demikian lama-kelamaan terus mengalami perubahan. Kelompok yang memiliki pandangan dan sikap demikian pun semakin mengecil. Misalnya, sadar akan ancaman terhadap apa yang telah dirintisnya, KH. Choer Affandy tidak melangkah jauh untuk ikut kembali pada politik praktis melawan negara. Karena hal tersebut akan menghancurkan lembaga pendidikan yang telah dibangunnya. Karena pada tahun 1980-an ia dikabarkan untuk tetap mendukung Negara Kesatuan Republik Indonesia (NKRI). Bahkan pada pertengahan 1980-an KH. Choer Affandy sempat dikabarkan berfiliasi dengan Golkar atas ajakan KH. Shahibul Wafa Tajul 'Arifin atau Abah Anom, pimpinan Pesantren Suryalaya Tasikmalaya dan KH. Ilyas Ruhiyat, pimpinan Pondok Pesantren Cipasung Tasikmalaya. Ia dekat dengan tokoh-tokoh Nasional, seperti Muhammad Natsir, Abdurrahman Wahid, dan Faisal Tanjung. Ketokohan dan kharisma KH. Choer Affandy ini banyak diakui oleh tokoh-tokoh nasional seperti Soekarno, Mohammad Natsir, Ibrahim Ajie, KH. Ilyas Ruhiyat, dan KH. Shohibul Wafa Tajul Arifin (Abah Anom, Pesantren Suryalaya). ${ }^{28}$

Alchaidar menyebutkan bahwa KH. Choer Affandy bukanlah seorang "negarawan" sejati, yang gigih mempertahankan NII sampai titik darah penghabisan. Ia bergabung dengan DI/TII pun karena kharisma keilmuan, bukan didasari oleh "ghairah berkuasa". Oleh karena itu, setelah kembali ke pangkuan NKRI, ia tidaklah menyusun stategi perang fisik, tetapi berupaya mewujudkan cita-citanya melalui jalur pendidikan dan dakwah. Inilah saatnya ia melakukan switch of paradigm dan reorientasi perjuangannya dari fisik ke pembangunan Sumber Daya Manusia dan sistem yang lebih damai dan kultural.

Dalam konteks ini, apa yang dilakukan oleh Pondok Pesantren Miftahul Huda adalah upaya -meminjam istilah Ronald A. Lukens-Bull- menempuh

\footnotetext{
${ }^{28}$ Wawancara KH. Abdul Fatah, salah satu sesepuh Pondok Pesantren Miftahul Huda, Tasikmalaya, 12 Februari 2015.
}

Walisongo, Volume 23, Nomor 1, Mei 2015 
jalan peaceful jihād (jihad damai).29 Term ini dimaknai dengan upaya jihad yang dilakukan secara damai dengan melalui pendidikan kesadaran tentang penegakan syari'ah dan penerapan nilai-nilai keislaman dalam segala aspek kehidupan, yakni ibadah, ekonomi, sosial, budaya, dan politik. Sikap dari KH. Choer Affandy dan para pengikutnya pun dinilai semakin "jinak", sekalipun kemudian sikap tersebut menimbulkan kebingungan di kalangan para kawan dan lawan. Keluarga dari KH. Choer Affandy mulai mengenyam pendidikan formal. Anak-anak nya seperti Asep Maoshul Affandi dan Abdul Aziz Affandi sempat mengenyam pendidikan hingga sekolah menengah, padahal sebelumnya belajar di sekolah pemerintah adalah sesuatu yang "diharamkan".

Sikap moderat dari Pondok Pesantren Miftahul Huda sangat kentara pada awal tahun 1994-an hingga kini, yakni ketika kepemimpinan pesantren berada di tangan anak-anaknya, yakni KH. Asep Maoshul dan KH. Abdul Aziz. Pada masa ini, upaya menurunkan tension radikal pada tingkat pemahaman dan sikap terus dilakukan. Misalnya, pada kerusuhan konflik horizontal bernuansa SARA di Tasikmalaya pada Desember tahun 1996. Pihak Pondok Pesantren Miftahul Huda merupakan pihak yang berkontribusi untuk memediasi dan memasilitasi rekonsiliasi dan rekonstruksi pasca-kerusuhan. Setidaknya, KH. Asep Maoshul dan KH. Didi Abdul Hidi, yang keduanya mewakili Pondok Pesantren Miftahul Huda berperan untuk menentramkan dan memobilisasi masyarakat agar tidak bersifat anarkis dan menjauhi kerusuhan berbasis SARA. Begitu pula ketika beberapa kiai yang berafiliasi ke Pondok Pesantren Miftahul Huda terlibat bentrokan dengan ormas lainnya seperti FPI atau kalangan preman, pihak Pondok Pesantren Miftahul Huda bereaksi secara proporsional, padahal untuk melakukan pegerahan massa dan melakukan anarkis adalah sesuatu yang mudah bagi mereka. Bahkan dengan pertimbangan keidentikan FPI dengan "tindakan kekerasan", KH. Asep Maoshul menyerukan agar semua kiai, santri, dan alumni Pondok Pesantren Miftahul Huda untuk keluar dari kepengurusan dan keanggotaan FPI. ${ }^{30}$

\footnotetext{
${ }^{29}$ Ronald Lukens-Bull, A Peaceful Jihād: Negotiating Identity and Modernity in Muslim Java, (New York: Palgrave Macmillan, 2005), h. 12

${ }^{30}$ Satu Harapan, “Oknum FPI Tasukmalaya Pukuli Pimpinan Miftahul Huda”, diunduh dari http://www.satuharapan.com/read-detail/read/oknum-fpi-tasikmalaya-pukuli-pimpinan-ponpesmiftahul-huda, diakses pada14 Oktober 2014.
} 


\section{E. Proses Deradikalisasi Pemahaman Keislaman}

Semakin sedikitnya pesantren, kiai, santri, dan simpatisan pesantren yang memiliki pandangan radikal ini tidak dapat dilepaskan dari upaya kalangan elit internal pesantren untuk meredam sikap "radikal", baik yang muncul dari sistem pendidikan, lembaga, maupun personal dari kalangan Pondok Pesantren Miftahul Huda pusat dan cabang. Namun, pihak pesantren memberikan penjelasan bahwa masih banyak kemungkinan bagi para provokator dan aktivis Islam Radikal untuk menyusupkan pengaruhnya di kalangan pesantren. Bagi Asep Maoshul, Pondok Pesantren Miftahul Huda tidak memiliki imunitas dari paham radikal, secara mutlak. Terlebih pada tataran pemikiran dan sikap yang "radikal" seringkali sulit terkontrol. Demikian pula, mereka yang tergabung dengan kelompok radikal pun masih sulit terlacak. Hanya saja, menurut KH. Asep Maoshul hingga kini tidak terditeksi santri di Miftahul Huda pusat dan cabang berafiliasi dengan kelompok radikal yang memiliki "pemikiran dan gerakan radikal".

Oleh karena upaya untuk membentengi dan mencegah (preventif) diri dari paham tersebut perlu dilakukan. Hal ini disebut dengan preventive de-radicalization. Secara intensif, pihak pesantren telah mengingatkan sejak dini (early warning) akan ancaman golongan radikal yang akan memanfaatkan pesantren agar sikap moderat dan damai senantiasa terjaga. Upaya ini dikenal dengan preservative de-radicalization. Selebihnya, upaya pun dilakukan pemulihan (recovery) bagi kalangan yang sudah terlanjur aktif di kelompok-kelompok radikal. Hal inilah yang dikenal dengan curative de-radicalization. Dengan demikian upaya deradikalisasi yang dilakukan Pondok Pesantren Miftahul Huda berkisar pada tiga strategi, yakni pencegahan (preventive de-radicalization), pemeliharaan budaya damai (preservative de-radicalization), dan pemulihan bagi yang terdampak radikal (curative de-radicalization).

Upaya yang dilakukan kalangan Pondok Pesantren Miftahul Huda untuk menjinakkan diri sendiri, membentengi dari paham radikal, dan melakukan recovery kalangan yang sudah terlanjur, melalui beberapa cara. Pertama, internalisasi nilai-nilai pesantren. Kedua, perluasan perspektif keislaman. Ketiga, adopsi sistem sekolah di lingkungan Pondok Pesantren Miftahul Huda cabang. Keempat, pendidikan cinta tanah air. Kelima, penggunaan local wisdom. Keenam, pendidikan dan pelatihan keterampilan. 


\section{F. Internalisasi Nilai-nilai Pesantren}

Pondok Pesantren Miftahul Huda, sebagaimana pesantren lainnya, mengorientasikan pendidikannya sebagai lembaga transmisi keilmuan Islam, reproduksi ulama, dan pemertahan tradisi. Selain ketiga peran tersebut, pesantren pun tumbuh dalam masyarakat untuk melayani berbagai kebutuhan mereka. ${ }^{31}$ Peran pesantren pun tumbuh menjadi lembaga keagamaan yang melakukan kontrol sosial (social control) dan juga rekayasa sosial (social engineering). ${ }^{32}$ Bahkan di saat, pendidikan modern, sekolah dan madrasah, belum menjamah pelosok pedesaan, pesantren mampu menjadi lembaga pendidikan alternatif bagi masyarakat. Karenanya tidak salah apabila kemudian pesantren diposisikan pula sebagai simbol yang menghubungkan dunia pedesaan dengan dunia luar. ${ }^{33}$

Dalam upaya mencapai peran dan fungsi di atas, Pondok Pesantren Miftahul Huda mencapainya melalui internalisasi nilai-nilai pesantren, yakni kemandirian, sesuai dengan nalar masyarakat, dan akomodatif terhadap tradisi di masyarakat. Dalam sejarahnya, para Wali Songo dan para arsitek pesantren menggunakan sikap akomodatif dalam Islamisasi di Nusantara, sehingga secara kultural Islamisasi mampu berhasil dan bertahan pada jiwa masyarakat. Pesantren memposisikan diri sebagai bagian dari masyarakat bahkan menjadi garda depan dalam perubahan sosial. Perubahan tersebut dilakukan melalui jalan hikmah dan damai, serta menghindari proses radikal dan revolusi. Dalam konteks inilah, Hiroko Horikoshi melihat bahwa perubahan sosial yang dilakukan pesantren memiliki karakteristik tertentu yang berbeda dengan ideologi lainnya, seperti developmentalisme, karena keberadaan aspek pembangunan etico-religious dalam konsep dan pergerakannya.

\section{G. Perluasan Perspektif Keislaman}

KH. Choer Affandy dikenal sebagai salah satu kiai kharismatik yang terbuka dengan berbagai mazhab Kalam, Fiqh, dan Tasawuf dalam lingkaran ideologi keagamaan Ahl al-Sunnah wa '-Jamā'ah (Aswaja). Sikap terbuka sebenarnya telah dinampakkan oleh nyasejak merintis pendirian pondok pesantrennya. Ia cukup

\footnotetext{
${ }^{31}$ Suprayetno Wagiman, “The Modernization of the Pesantren's Educational System to Meet the Needs of Indonesia Communities", tesis, tidak dipublikasikan, (Montreal: McGill University, 1997), h. 92-105.

${ }^{32}$ Ditjen Kelembagaan Agama Islam Departemen Agama Islam, Direktori Pesantren, Oakarta: Depag RI, 2004), h. 8.

33M.M. Billah, "Pikiran Awal Pengembangan Pesantren", dalam Dawam Raharjo (ed.). Pergulatan Dunia Pesantren, Membangun Dari Bawah, (Jakarta:P3M, 1985), h. 290.
} 
diterima oleh setiap kalangan dari ormas-ormas yang ada di sekitar pesantrennya di Tasikmalaya serta dikenal bukan hanya karena kharisma keilmuannya, tetapi sikap terbukanya terhadap berbagai paham keislaman. Sekalipun demikian ia memiliki ketegasan dalam hal memberikan fatwa dan nasihat.

KH. Choer Affandy menulis cukup banyak karya tulis, dan sebagian besarnya ditulis dalam bentuk nazm. Karya-karyanya yang sempat terinventarisir adalah sebagai berikut: 1) 50 'Aqīdah 'Ajamin Mu'min Munjin; 2) 'Aqīdah Islāmiyyah; 3) Asrār Asmā al-Ḥusnā; 4) Kupasan Lengkap al-Asmā al-Husnā; 5) Naẓaman Sunda Syahadatain \& Kalimah Thoyyibah; 6) Nazm Istighāthah; 7) Nazm Sunda Hidāyat al-Atqiyā'; 8) Nażm Sunda Majmū'àt al-'Aqìdah Juz Awwal; 9) Nazm Sunda Majmū'āt al-'Aqīdah Juz al-Thāniy; 10) Nażm Sunda Safinat al-Najāḥ; 11) Pangajaran Aqāidd al-İmān; 12) Sunda Qiyasan; 13) Tarjamah Kitab Bainamā (Sejarah Isra Mi'raj); 14) Tarjamah Sunda Bacaan Shalat Fardlu; dan 15) Tawdịh Tijān alDurary. Pada karya-karyanya ini, keislaman ditampakkan dengan wajah Islam yang damai dan moderat sebagai bagian dari penghambaan manusia kepada Allah dalam menjalani tugas dan fungsinya sebagai 'abd Allah dan khalifah Allah

Secara kelembagaan, perluasan perspektif dilakukan dengan cara membangun organisasi dan kelembagaan yang semi-modern, yang menerapkan diversifikasi strukutual dan kultural yang jelas. Mereka pun melakukan studi komparatif ke berbagai wilayah dan negara (seperti Turki dan Timur Tengah, bahkan Iran) untuk mengembangkan lembaga pendidikan yang berkarakter, berdaya saing, dan modern. Secara akademis, perspektif diperluas dengan memperkaya khazanah kitab-kitab klasik, terutama perbandingan hukum dan mazhab. Selain itu, sistem pengajian bandongan, mudhākarah, dan munäzarah dilakukan untuk membangun kemampuan retorika dan saling membuka diri terhadap saran dan kritik. Dengan kata lain, demokrasi diperkenalkan dan dibiasakan, sekalipun secara terbatas dalam kerangka "kultur santri" atau "budaya pesantren." 34

Pihak Pondok Pesantren Miftahul Huda tidaklah alergi dengan mazhab lainnya. Sekalipun mereka menampakkan ketidaksetujuannya dengan kalangan Salafi-Wahabi, Ahmadiyyah, dan Syi'ah, namun mereka melakukannya secara damai, misalnya melalui adu argumentasi dan tidak mendorong pada

\footnotetext{
${ }^{34}$ Ronald Lukens-Bull menyatakan, "Another key aspect of pesantren education is character development. The lif style of the student is ascetic. Spontan living conditions, simple food, a demanding study schedule, and strict obedience to their teacher, called "kiai". Ronald Lukens-Bull, A Peaceful Jihäd: Negotiating Identity and Modernity in Muslim Java, (New York: Palgrave Macmillan, 2005), h. 12
} 
upaya radikalitas fisik. Mereka menggunakan negosiasi dan jalur hukum untuk meredam pengaruh Ahmadiyyah dan Syi'ah. Begitu pula ketika mereka berkontribusi pada peredaman penistaan Agama yang dilakukan oleh Sensen Komara, pentolan DI, melalui jalur damai, dan meminimalisir jalan kekerasan.

Pada bagian ini, upaya penumbuhan karakter moderat didasari pada upaya pengenalan (moral knowing), internalisasi (moral feeling), hingga praktek (moral action). Ketiga tahapan tersebut dipenuhi dengan unsur-unsur substansi keislaman, baik pada aspek ideal (das sollen) maupun aspek praktek penubuhannya dalam sejarah (das sein). Di sadari pada upaya menyinkronkan antara idealitas dan realitas mempunyai tantangannya tersendiri. Oleh karena itu, kesadaran tentang proses (consciousness on process) diperlukan agar terjadi inovasi dan kreativitas.

\section{H. Adopsi Sistem Sekolah di Pesantren}

Menurut KH. Abdul Fatah, era tahun 1970-1980-an, Pondok Pesantren Miftahul Huda mengalami perkembangan yang luar biasa hingga mampu menjelma menjadi pesantren salafiyah terbesar di Jawa Barat. Namun, seiring perkembangan sekolah dan perubahan persepsi masyarakat tentang pesantren, maka perkembangan pesantren salafiyah kemudian menurun pamornya. Banyak di antara pesantren salaf yang kemudian gulung tikar. Menurut KH. Abdul Fatah, Pondok Pesantren Miftahul Huda bernasib lebih baik dibanding pesantren salafiyah lainnya, karena masih dapat bertahan hingga sekarang.

Menurut KH. Ahmad Syafi'i, pimpinan Pondok Pesantren Miftahul Huda AlFaqih salah satu faktor yang menjadikan Pondok Pesantren Miftahul Huda bertahan karena distribusi fungsional lembaga pendidikan yang tergabung di Pondok Pesantren Miftahul Huda. Pondok Pesantren Miftahul Huda pusat difungsikan sebagai lembaga ma'had 'aliy atau takhașsus, yang tetap mempertahankan diri sebagai lembaga pendidikan salafiyah (tradisional). Sedangkan, bagi masyarakat yang menginginkan nyantri sambil sekolah, mereka dapat tinggal di pesantren-pesantren cabang. Sebagian Pondok Pesantren Miftahul Huda telah membuka diri dengan sistem sekolah dan madrasah. Beberapa pondok pesantren cabangnya telah membuka madrasah diniyyah (madrasah takmīliyyah), madrasah formal, dan sekolah. ${ }^{35}$ Fenomena adopsi sekolah atau

${ }^{35}$ KH. Ahmad Syafi'i, Pimpinan Pondok Pesantren Miftahul Huda al-Faqih yang juga merupakan salah satu cabang ponpes Miftahul Huda, wawancara: Tasikmalaya, 12 Februari 2015. 
madrasah seperti ini, seakan-akan sulit dihindari oleh kalangan pesantren, sebagaimana diprediksi oleh Karel Steebrink. ${ }^{36}$

Kesadaran akan pentingnya pendidikan formal ini tumbuh dari kalangan internal dan juga karena tuntutan eksternal. KH. Abdul Fatah dan KH. Abdul Aziz menyebutkan bahwa KH. Choer Affandy pernah memunculkan gagasan untuk menjadikan Pondok Pesantren Miftahul Huda sebagai pesantren modern. Namun, kemudian niat tersebut diurungkannya karena melihat banyak pesantren yang beralih fungsi dan bahkan gulung tikar gara-gara membuka sekolah. Hanya saja, putra-putri dan cucu KH. Choer Affandy merasakan perlu untuk mengenyam pendidikan formal. Berbekal kompetensi dan persyaratan formal administrasi, yakni ijazah, pula yang kemudian mengantarkan keduanya sebagai pengurus Partai Politik. Bahkan Asep Maoshul mampu menjadi anggota DPR RI selama dua periode (2009-2014 dan 2014-2019). Selebihnya, cucu KH. Choer Affandy, yakni UU Ruzhanul Ulum yang merupakan lulusan S1 di al-Musaddadiyyah, mampu menjadi Bupati Tasikmalaya karena salah satunya mampu memenuhi persayaratan administrasinya, yakni memiliki ijazah.

Menurut KH. Ahmad Safi'i, diakui atau pun tidak, pendidikan yang didapat di sekolah atau madrasah telah mampu memperkaya khazanah keilmuan, pengalaman, dan pola perilaku dari kalangan santri. Pada sisi materi, santri memiliki wawasan geopolitik, wawasan kebangsaan, dan kesadaran sejarah nasional yang lebih banyak dibanding para santri yang tidak mengenyam pendidikan formal. Selebihnya pada aspek toleransi dan penghargaan terhadap keragaman, para santri yang sekolah memilikinya secara fungsional dibanding para santri non-sekolah yang hanya bersifat normatif.

\section{Pendidikan Cinta Tanah Air (Hubb al-Wathan)}

Beberapa program yang didesain oleh Pondok Pesantren Miftahul Huda diorientasikan sebagai bagian dari cinta tanah air (hub al-wațan). Pendidikan model in pernah diterapkan oleh Hadratu Syeikh Hasyim Asy'ari untuk menumbuhkembangkan jiwa kecintaan terhadap bangsa dan negara. Bentuknya dari mulai pendidikan kepramukaan (pandu), maupun Santri Siap Guna (SSG). Bagi santri takhassus kegiatan ini pun dilakukan dalam Pekan Orientasi Santri Ma'had 'Aliy (POSMA). Model ini diadaptasi oleh KH. Abdulllah Gymnastiar atau

${ }^{36}$ Karel Steenbrink, Pesantren, Sekolah, Madrasah, (Jakarta: LP3S, 1994). 
Aa Gym, salah satu alumni Pondok Pesantren Miftahul Huda, di Pesantren Daarut Tauhid Bandung.

Kegiatan ini dilakukan sebagai upaya pengenalan lapangan dakwah bagi santri-santri ma'had 'aliy agar para mereka mempunyai bekal ketika kembali ke masyarakat. Mereka dilatih untuk mengenali situasi, kondisi, dan kebutuhan sosial-keagamaan (socio-religious need) masyarakat, sehingga mereka akan mudah bersosialisasi, beradaptasi, dan bermasyarakat, sehingga mampu mempercepat keberhasilan proses dakwah dan pendidikan. Pada beberapa kesempatan, pesantren pun menyelenggarakan pendidikan dan pelatihan in service training untuk membekali para santri senior beberapa keterampilan yang dapat dikembangkan sebagai profesi, baik untuk dirinya maupun untuk santri-santrinya jika mereka membuka lembaga pendidikan.

Pada beberapa kesempatan, para kiai juga menyisipkan beberapa tema tentang "Kewaspadaan terhadap paham Fundamentalis, Radikalisme, dan Terorisme". Tema-tema ini diperkenalkan agar para santri dan warga pesantren mampu mengenali kalangan Islam-radikal ini serta mampu menghindari diri pengaruh mereka. Bahkan secara lebih jauh, mereka berusaha pula untuk membentengi keluarga dan masyarakat tentang bahaya laten terorisme, radikalisme, dan fundamentalisme. Mereka sangat aktif untuk mempertahankan berbagai tradisi ekpressi kultural masyarakat Muslim nusantra yang terkenal adaptif terhadap berbagai budaya lokal.

\section{J. Penggunaan Local Wisdom}

Setidaknya ada beberapa falsafah lokal Sunda (Jawa Barat) yang digunakan kalangan Pondok Pesantren Miftahul Huda untuk menyampaikan Islam Ramah (Smile Islam), yakni: (a) Silih Asah, Silih Asih, Silih Asuh; (b) Falsafah 5 R (dulur sakasur, dulur sadapur, dulur sasumur, dulur salembur, dulur sagubernur). Falsafah silih asah, silih asih, silih asuh bermakna "saling bantu, saling kasih, saling mengayomi". Falsafah ini digunakan untuk mengembangkan sifat kompetitif yang didasari dasar kasih sayang dan saling mengasuh. Melalui pembelajaran falsafah pertama ini pun, para kiai dan santri diarahkan untuk membangun kesadaran tentang keragaman struktural dan kultural (cultural and structural diversification), di mana individu dan kelompok mempunyai peran dan fungsinya masing-masing. Keragaman itu tidak untuk dijadikan perselisihan dan pertentanga, tetapi dapat digunakan sebagai upaya membangun kebersamaan dalam persaingan sehat (fastabiq al-khairāt). 
Sementara falsafah kedua bermakna leveling persaudaran, dari saudara pada tingkat kecil hingga saudara tingkat yang lebih luas. Dulur sakasur bermakna "saudara satu kasur", sedangkan dulur sadapur bermakna "saudara satu dapur". Keduanya bermakna saudara serumah. Dulur sasumur (saudara satu sumur) berarti persaudaraan dengan tetangga yang dekat. Sedangkan dulur salembur (saudara satu kampung) dan dulur sagubernur (saudara satu provinsi) bermakna persaudaraan satu kampung dan satu wilayah se-provinsi. Falsafah ini digunakan untuk membangun kesadaran ukhuwwah insāniyyah, ukhuwwah Islāmiyyah, serta ukhuwwah wațaniyyah.

Pada sisi ini pun, pihak kiai dan asatidz seringkali menjelaskan tentang keragaman dan perbedaan ras, bahasa, dan suku bangsa sebagai bagian dari sunnatullah. Perbedaan tidak untuk disikapi sebagai pertentangan dan permusuhan, tetapi harus dijadikan rahmat li 'l-ālamìn dan energi positif untuk memperkokoh fundamental kebangsaan Indonesia.

\section{K. Pendidikan Keterampilan}

Salah satu faktor yang dapat memicu radikalisme dan konflik sosial agama adalah kemiskinan, kesenjangan kesejahteraan, dan tidak meratanya distribusi pembangunan. Pesantren yang umumnya hidup di kalangan masyarakat desa yang miskin diharapkan mampu menjadi agen perubahan sosial (agent of social change). ${ }^{37}$ Kemampuan ini telah dibuktikan oleh Hiroko Hirokosi sebagaimana pada kasus-kasus kiai di Jawa Barat yang mampu memerankan diri untuk menggerakan pesantren dan masyarakat untuk melakukan mobilisasi sosial dan struktural. Dalam hal ini, para elit pesantren tidak hanya menjadi "makelar budaya" sebagaimana dikatakan Clifford Geertz, ${ }^{38}$ tapi mampu menjadi pionir perubahan dan pembangunan masyarakat.

Untuk melatih dan mengembangkan kreativitas para santri, sekaligus untuk meningkatkan kesejahteraan para guru dan pegawai, Pondok Pesantren Miftahul Huda mendirikan tujuh macam unit usaha, yaitu Wartel, Suq Shagir (mini market), kantin, Kelompok Bimbingan Ibadah Haji (KBIH), Baitul Mal wa

\footnotetext{
${ }^{37}$ Social Control dan Social Engineering merupakan konsep yang dikeluarkan oleh Hiroko Horikoshi untuk peran dan fungsi kiai dalam perubahan sosial. Lihat Hiroko Horikoshi, Kyai dan Perubahan Sosial, (Jakarta: P3M, 2001).

${ }^{38}$ Konsep yang diintrodusir Clifford Geertz. Lihat misalnya dalam dalam "The Javanese Kjaji: The Changing Role of a Cultural Broker", CSSH (1959-1960) Vol. II, h. 228-249, memasukkan peran lain dari kiai atau ulama yakni sebagai "makelar budaya" (cultural broker).
} 
al-Tamwil (BMT), Radio Siaran Miftahul Huda (Rasimuda), Dealer Motor Kanzen, pom bensin, dapur umum, dan koperasi pondok pesantren. ${ }^{39}$ Semua jenis usaha tersebut dikelola oleh pesantren secara langsung dengan melibatkan para santri dan sebagian ustadz, yang semuanya di bawah bimbningan dan pengawasan kiai pimpinan pesantren. ${ }^{40}$

Pesantren cabang Miftahul Huda pun didorong mengembangkan lembaganya dengan mengikuti beberapa program yang diselenggarakan oleh Pondok Pesantren Miftahul Huda pusat sebagai hasil kerjasama dengan berbagai pihak. Misalnya pada tahun 2013-2016, Kementrian BUMN (ketika masih dipimpin Dahlan Iskan) bekerja sama dengan Pondok Pesantren Miftahul Huda pusat, yang melibatkan cabang-cabang Pondok Pesantren Miftahul Huda, untuk program reboisasi dan diversifikasi lahan-lahan tidur (non-produktif) sejumlah 1000 Hektar di wilayah Jawa Barat. Nilai proyeknya berjumlah miliyaran rupiah (tidak semua dalam bentuk rupiah atau non-rupiah murni) dan mampu melibatkan cabang-cabang Miftahul Huda. ${ }^{41}$

\section{Kesimpulan}

Pondok Pesantren Miftahul Huda pada masa awal sangat lekat dengan stigma "radikal". Kerekatan ini dipicu oleh beberapa hal. Pertama, kerekatan historis sosok pendiri pondok pesantren ini yakni KH. Choer Affandy dengan gerakan DI/TII karena ia pernah menjadi salah satu elitnya. Kedua, sikap kritisisme elit, santri, dan simpatisan Pondok Pesantren Miftahul Huda terhadap Pemerintah Orde Baru. Ketiga, beberapa teman seperjuangan KH. Choer Affandy dan santri-santri generasi awalnya masih memiliki ideologi NII. Keempat, sebagian kalangan Pondok Pesantren Miftahul Huda memandang keberislaman diri dan kelompok mereka adalah keberislaman yang paling benar, sementara yang lain dianggap memiliki kekurangan atau bahkan "salah." Kelima, pandangan eksklusif kalangan pesantren terhadap "dunia luar", seperti Pemerintah dan masyarakat pro-Pemerintah beserta produk-produk turunannya, seperti program sekolah, keluarga Berencana (KB), uji screening, dan asas tunggal.

\footnotetext{
${ }^{39}$ Monografi Sekterariat Pondok Pesantren Miftahul Huda 2012

40Mahrus As'ad, "Sumbangan Pesantren terhadap Pencapaian Tujuan Pendidikan Nasional." Disertasi, tidak diterbitkan, (Bandung: Pascasarjana UIN SGD, 2010, h. 200.

41Wawancara dengan KH. Asep Maoshul, Tasikmalaya, 12 Februari 2015.
} 
Seiring dengan perjalanan waktu, Pondok Pesantren Miftahul Huda pun melakukan pembenahan diri sehingga mampu menampilkan diri sebagai lembaga yang ramah dan moderat. Orientasi perjuangan pun mengalami reorientasi dari perjuangan fisik ke arah perjuangan melalui jalur pendidikan dan dakwah kultural dan struktural atau -meminjam terminology Lukens-Bullmelalui Jihad Damai (peaceful jihād). Upaya deradikalisasi yang dilakukan Pondok Pesantren Miftahul Huda berkisar pada tiga strategi, yakni pencegahan (preventive de-radicalization), pemeliharaan budaya damai (preservative deradicalization), dan pemulihan bagi yang terdampak radikal (curative deradicalization).

Upaya yang dilakukan kalangan Pondok Pesantren Miftahul Huda untuk menjinakkan diri sendiri, membentengi dari paham radikal, dan melakukan recovery kalangan yang sudah terlanjur, melalui beberapa cara. Pertama, internalisasi nilai-nilai pesantren. Kedua, perluasan perspektif Keislaman. Ketiga, adopsi sistem sekolah di lingkungan Pondok Pesantren Miftahul Huda cabang. Keempat, Pendidikan cinta tanah air. Kelima, penggunaan local wisdom. Keenam, pendidikan dan pelatihan keterampilan.[w] 


\section{BIBLIOGRAFI}

Agusandi, Insan M., "Perkembangan Pondok Pesantren Miftahul Huda dan Dampaknya terhadap Kehidupan Sosial Keagamaan Kabupaten Tasikmalaya (1980-2009)," skripsi di Jurusan Pendidikan Sejarah UPI Bandung, 2013.

As'ad, Mahrus, "Sumbangan Pendidikan Pesantren terhadap Pencapaian Tujuan Pendidikan Nasional," disertasi, tidak diterbitkan, Bandung: Pascasarjana UIN SGD, 2010.

Azra, Azyumardi, Pergolakan Politik Islam: Dari Fundamentalisme, Modernisme hingga Postmodernisme, Jakarta: Paramadina,1996.

Effendi, Bahtiar dan Hendro Prasetyo (ed.), Radikalisme Agama, Jakarta: PPIMIAIN,1998.

Esposito, John L, The Islamic Threat Myth or Reality? Oxford: Oxford University Press, 1992.

Fattah, KH. Abdul, Awal Mula Uwa Ajengan Datang Ke Manonjaya, Bandung: CV. Wahana Iptek Bandung, 2010.

Fazari, Mahdar, Ikhlas Mengabdi: Biografi Uwa Ajengan Pendiri Pondok Pesantren Miftahul Huda Manonjaya Tasikmalaya Jabar, Tasikmalaya: Yayasan Pondok Pesantren Miftahul Huda,1996.

Hanafi, Hassan, Agama, Kekerasan dan Islam Kontemporer, terj. Ahmad Najib. Yogyakarta: Jendela, 2001.

Hefner, Robert W, Making Modern Muslims; The Politics of Islamic Education in Southeast Asia, Univerity of Hawaii Press, 2009.

Hidayat, Komaruddin, Tragedi Raja Midas: Moralitas Agama dan Krisis Modernisme, Jakarta: Paramadina, 1998.

Horikoshi, Hiroko, Kyai dan Perubahan Sosial, Jakarta: P3M, 2001.

al-Jabiri, Muhammad Abid, Agama, Negara dan Penerapan Syariah, Yogyakarta: Fajar Pustaka, 2001.

Lukens-Bull, Ronald, A Peaceful Jihād: Negotiating Identity and Modernity in Muslim Java, New York: Palgrave Macmillan, 2005. 
Martin van Bruinessen, "Tradisionalist and Islamist Pesantrens in Contemporary Indonesia", dalam Farish A. Noor, et.al. (ed.), The Madrasa in Asia, Political Activism and Transnational Linkages, Amsterdam: Amsterdam University Press, 2008.

Mastuhu, Dinamika Sistem Pendidkan Pesantren: Suatu Kajian tentang Unsur dan Nilai Sistem Pendidikan Pesantren, Jakarta: Indonesian-Netherlands Coperation in Islamic Studies, 1994.

Mustari, Mohamad, Peranan Pesantren dalam Pembangunan Pendidikan Masyarakat Desa, Yogyakarta: MultiPress, 2011.

Pesantren Miftahul Huda, Sejarah Berdirinya Pesantren Miftahul Huda Manonjaya, Tasikmalaya, 1969.

Pondok Pesantren Miftahul Huda, Demografi Sekterariat Pondok Pesantren Miftahul Huda, Tasikmalaya, 2012.

S.S. Misra, "Islamic Terrorism in Indonesia", dalam ASIAN Affairs, September 20032003.

Steenbrink, Karel A, Pesantren, Madrasah dan Sekolah, Jakarta: LP3ES, 1994.

Sunarya, Yuyun, "Hubungan Fungsional Radio FM Rasimuda terhadap Pondok Pesantren Miftahul Huda Manonjaya-Tasikmalaya," skripsi, Yogyakarta: Jurusan KPI Fakultas Dakwah UIN Sunan Kalijaga, 2008.

Syahidin, "Komunikasi Kyai-Santri di Pondok Pesantren Miftahul Huda Manonjaya Tasikmalaya dalam Membina Kepribadian; Suatu Upaya Pengembangan Komunikasi Guru-Murid dalam Pendidikan Umum," tesis, tidak dipublikasikan, Bandung: IKIP Bandung, 1994.

Tebba, Sudirman, Islam Pasca Orde Baru, Yogyakarta: Tiara Wacana, 2001.

\section{Wawancara:}

KH. Abdul Fatah (75 Tahun), salah satu Pimpinan Pondok Pesantren Miftahul Huda Manonjaya Tasikmalaya, 12 Pebruari 2015.

KH. Asep Maoshul (53 Tahun), Pimpinan Umum Pondok Pesantren Miftahul Huda Manonjaya Tasikmalaya, 12 Pebruari 2015.

KH. Ahmad Syafi'i (49 Tahun), Pimpinan Pondok Pesantren Miftahul Huda AlFaqih, cabang Pondok Pesantren Miftahul Huda Pusat Manonjaya Tasikmalaya, 12 Pebruari 2015.

Walisongo, Volume 23, Nomor 1, Mei 2015 
KH. Abdul Aziz Affandy (51 Tahun), salah satu Pimpinan Pondok Pesantren Miftahul Huda Manonjaya Tasikmalaya, 23 Januari 2015.

KH. Sholeh Nasihin (63 Tahun), salah satu Pimpinan Pondok Pesantren Miftahul Huda Manonjaya Tasikmalaya, 5 Pebruari 2015.

KH. Saeful Uyun (62 Tahun), Ketua Hamida (Himpunan Alumni Miftahul Huda) dan Pimpinan Pondok Pesantren Gempalan, Kecamatan Panjalu, Ciamis, 22 Januari 2015. 